\title{
Structure, physical properties, and flame retardancy of POE/NR/EG blend foams: Effect of crosslinking
}

\author{
Karnjana Sawangpet a, Alif Walong a , Azizon Kaesaman a, Bencha Thongnuanchan a, Tadamoto \\ Sakai ${ }^{\mathrm{b}}$ and Natinee Lopattananon ${ }^{\mathrm{a},{ }^{*}}$ \\ a Department of Rubber Technology and Polymer Science, Faculty of Science and Technology, Prince of Songkla University, Pattani, Thailand \\ b Tokyo Office, Shizuoka University, 3-3-6 Shibaura, Minato, Tokyo, 108-0023, Japan \\ * Corresponding author: natinee.l@psu.ac.th
}

Article history

Received 7 February 2019

Revised 17 April 2019

Accepted 5 October 2019

Published Online 2 February 2020

\begin{abstract}
Elastomeric foams were produced by melt-mixing of polyethylene-octene elastomer (POE), natural rubber (NR), and expandable graphite (EG) in an internal mixer. The blend was later foamed by compression-molding method. EG was used as a filler to enhance flame retardancy of the blend foams. Dicumyl peroxide (DCP) was used as curative to crosslink the blend foams. The influence of DCP content $(0.5,0.7,0.9$, and 1.0 part(s) by weight, pbw) on rheological properties, structure, density, mechanical properties, thermal conductivity, and flame retardancy of the POE/NR/EG blend foams was investigated. The rheological analysis showed that the melt strength/viscosity of the $\mathrm{POE} / \mathrm{NR} / \mathrm{EG}$ blend foams increased with more DCP addition due to promoted crosslinking in the blend foams. The cellular structural observation by SEM technique revealed that the POE/NR/EG blend foams had close-cell structure. Increasing DCP content, the blend foams had smaller cell and narrower cell size distribution. The degree of porosity, however, was highest for the foamed blends added with $0.7 \mathrm{pbw}$ DCP, which brought about the lowest thermal conductivity. Furthermore, it was found that the density, tensile strength, elastomeric recovery, and compressive strength increased with increasing content of DCP, but the elongation at break decreased. The POE/NR/EG blend foams reached the horizontal burning level of HF-1, and their oxygen index increased in accordance with an increase of DCP content. The results indicated that an appropriate use of DCP was critical for the crosslinked POE/NR/EG blend foams with optimum cellular structure, providing the best improvement in thermal insulation properties and good flame retardancy.
\end{abstract}

Keywords: Polyethylene-octene elastomer; natural rubber; foam; morphology; physical properties

\section{INTRODUCTION}

Polyethylene-octene elastomer (POE), a metallocene-based polyolefin, is one of the commercially important elastomers that is widely used in diverse applications ranging from foamed materials, automotive parts, durable goods, gaskets, to sealants impact modifiers in engineering plastics (Mao \& Qi, 2008; Sun \& Liang, 2016; Tayefi et al., 2017). Particularly, the foams fabricated from POE are commonly used in thermal insulation, construction fields, and electronic materials such as wire and cables because they show good balance of physical properties, i.e., good flexibility, thermal and UV stability, aging resistance, and excellent toughness, along with favorable processability (Svoboda et al., 2013; Guo et al., 2018). However, the aforementioned applications of elastomeric POE foams are affected by the unfavorable mechanical properties, i.e., low strength, high compression set, and high flammability. Therefore, from the viewpoints of mechanical property enhancement and flameretardant materials, the production of rubbery POE foam with required properties for industrial practice becomes a necessity.

Natural rubber (NR), a natural polymer, is an important elastomer in rubber industry, particularly for tire manufacturing (Cornish, 2014, Spratte et al., 2017). It has high tensile strength, tear strength, good elastomeric recovery, and low heat built-up. Previously, NR has been used as the main polymers or a value-enhancing component in compound formulation for polyolefin-based blend foams (Lopattananon et al., 2014a; Lopattananon et al., 2015; Julyanon et al., 2015; Lopattananon et al., 2018a). Julyanon et al. (2015) improved the cell morphology (i.e., greater cell density and smaller cell size), tensile strength, and elastic recovery of polyolefin-based blend nanocomposite foams by compounding ethylene vinyl acetate (EVA) rubber with NR as a modifier at various concentrations $(0,10$, 20, 30, and $40 \mathrm{wt} \%)$. Furthermore, the best improvement level was achieved when the loading of NR was at $40 \mathrm{wt} \%$.

Expandable graphite (EG) is a particular intumescent additive that has been widely used in foams and coatings to impart flame retardant properties for many polymeric materials due to its good flame retardant efficiency and low pollution potential (Chen et al., 2007; Thirumal et al., 2008; Zhang et al., 2013; Guler et al., 2017; Mngomezulu et al., 2018; Pang et al., 2018; Wang et al., 2018). Unfortunately, the dispersion of EG in several polymeric foams presents some serious problems, that are low strength, rough skin, and non-uniform cellular structure (Shi et al., 2005; Lorenzetti et al., 2017). Shi et al. (2005) added the EG in polyurethane (PU) foam at different addition levels $(0-20 \mathrm{wt} \%)$. They found that the cellular structure of the PU foams in the presence of EG fillers was inhomogeneous, which caused a decrease in compressive modulus and strength. However, increasing EG filler content significantly improved flame-resistant property as measured by limiting oxygen index (LOI) test. The addition of EG in PU foams resulted in nonuniform cell structure with large cell size and a decrease in mechanical properties, as well as thermal insulation property (Lorenzetti et al., 2017). To eliminate a series of limitation in the EG- 
filled polymeric foams, various methods can be used to improve the foam structure and the functional properties of polymeric foams such as additives input and crosslinking (Lopattananon et al., 2014a; Lopattananon et al., 2015; Lopattananon et al., 2018a).

From an industrial standpoint, one of the common approaches to optimize the cellular structure and to obtain desirable physical properties is the incorporation of crosslinking in the foams (Jacob, 2008; Shih et al., 2011; Feng et al., 2016). Practically, the peroxides are usually used to crosslink most rubbers and plastics due to economical reason. In the past, the experimental results revealed that the use of dicumyl peroxide (DCP) as crosslinking agent greatly affected the morphologies, mechanical properties, and foamability of polymeric foam (Shih et al., 2011; Yamagushi \& Suzuki, 2001; Li et al., 2013). Shih et al. (2011) improved the mechanical properties of footwear insole based on poly(styrene-b-butadiene-b-styrene) (SBS)/polystyrene (PS)/styrene-butadiene rubber (SBR) blend foams by an addition of DCP. The addition of appropriate content of DCP could improve the cellular structure of poly (butylene succinate) (PBS) foam and enhance the efficiency of blowing agent (Li et al., 2013).

To our best knowledge, no attempt has been made to improve the structure, physical properties, and fire performance of the POE foam through the addition of NR and EG. Therefore, in this study, POE and NR were mixed at selected composition of $60 / 40 \mathrm{wt} \%$ with $20 \mathrm{phr}$ EG. The addition level of EG (20 phr) was selected because the previous works have demonstrated their effectiveness in flame retardancy of polymers (Bian et al., 2007). The POE/NR/EG blend was later compounded using azocarbonamide (ADC) as foaming agent, trimethylolpropane trimethacrylate (TMPTMA) as co-curative, and DCP. Finally, the POE/NR/EG blend compounded with ADC, TMPTMA, and DCP was formed by compression molding. Since the crosslink degree of rubber foams can be easily controlled by the amount of peroxides, the effects of DCP contents on rheological properties, foam structure, foam density, mechanical properties, thermal conductivity, and flame-retardant properties were investigated.

\section{EXPERIMENTAL}

\section{Materials}

Polyethylene-octene elastomer (POE, Grade 8100) with an octene content of $38 \%$ and melt flow index of $1 \mathrm{~g} / 10 \mathrm{~min}\left(190{ }^{\circ} \mathrm{C} / 2.16 \mathrm{~kg}\right)$ was supplied by Dow Chemical Co., Ltd. (Thailand). It has Mooney viscosity (ML 1+4 $\left(100{ }^{\circ} \mathrm{C}\right)$ ) of 48 and density of $0.870 \mathrm{~g} / \mathrm{cm}^{3}$. Ribbed smoked sheet (Grade RSS\#3) NR with Mooney viscosity (ML $\left.1+4\left(100^{\circ} \mathrm{C}\right)\right)$ of 80 was supplied by Rubber Farmer Organization of Khokpho-Maelarn (Pattani, Thailand). Azodicarbonamide (ADC, Grade Cellcom-AC300F) supplied by Innovation Co., Ltd. (Thailand) was used as a blowing agent. This material had decomposition temperature of $201-208{ }^{\circ} \mathrm{C}$ and gas yield of $215-225 \mathrm{ml} / \mathrm{g}$. Zinc oxide (Univentures Public Co., Ltd, Thailand) and stearic acid (Imperial Chemical Co., Ltd, Thailand) were used as kickers to decrease the decomposition temperature of blowing agent in foaming process. Dicumyl peroxide (DCP, Wuzhou International Co., Ltd., China) was used as a vulcanizing agent. Trimethylolpropane trimethylacrylate (TMPTMA) (Behn Meyer Chemical Co., Ltd., China) was used as a co-vulcanizing agent. 2,2,4-trimethyl-1,2-dihydroquinone (TMQ) (Flexys, US) was used as an antioxidant. Paraffinic oil (White oil grade A no. 15, China Petrochemical International Co., Ltd, China) was used as a plasticizer to reduce the viscosity difference of POE/NR blend. Expandable graphite with sulfuric acid was used as an intercalating agent (EG, Grade L-200, Metachem Manufacturing Company Pvt Ltd., Maharashtra, India) was used as a flame-retardant filler. It has mean particle size of $191.87 \mu \mathrm{m}$ with size distribution ranging from $20-450 \mu \mathrm{m}$ and density of $1.55 \mathrm{~g} / \mathrm{cm}^{3}$. The expansion rates of EG grade L-200 are 14, 44, and $205 \mathrm{ml} / \mathrm{g}$ at 200,300, and 500 ${ }^{\circ} \mathrm{C}$, respectively.

\section{Preparation of POE/NR/EG foam}

A two-step melt mixing was used to prepare the EG-filled POE/NR foams. Firstly, POE pellets, NR, and EG were melt-mixed in Brabender plastograph model 815653 (Brabender GmbH \& Co. Ko, Germany) at a temperature of $70{ }^{\circ} \mathrm{C}$ and rotor speed of $60 \mathrm{rpm}$. The $60 / 40 \mathrm{wt} \%$ POE/NR foams were prepared by adding the EG filler content at $20 \mathrm{phr}$. To enhance the degree of mixing between POE, $\mathrm{NR}$, and EG in this work, we employed the stepwise masterbatch mixing (SMB) method (Lopattananon et al., 2018b). According to the SMB approach as schematically shown in Fig. 1, the POE and NR were firstly mixed with EG separately to prepare masterbatches of $\mathrm{POE} / \mathrm{EG}$ and NR/EG blends. The NR/EG masterbatch was also added with processing oil to lower the viscosity ratio of NR and POE, and to promote a mixing of NR with POE. The two different masterbatches were later mixed, and subsequently added with other additives according to ingredients given in Table 1 . Then, the obtained EGfilled POE/NR blends were compounded on a two-roll mill at $70{ }^{\circ} \mathrm{C}$ for $12 \mathrm{~min}$. The blends were added with azodicarbonamide $(5.0$ part(s) by weight, pbw) and with different DCP content $(0.5,0.7,0.9$, and 1.0 pbw). Finally, TMPTMA (4.0 pbw) was added in the blends compounds. The compounds were hot-pressed to a $90 \%$ cure in a mold with a hydraulic pressure at $160{ }^{\circ} \mathrm{C}$ cure temperature. The cure time of rubber blend foams was determined by the Moving Die Rheometer (MDR) at test temperature of $160{ }^{\circ} \mathrm{C}$. After that, the pressure was removed, and the samples were allowed to expand.
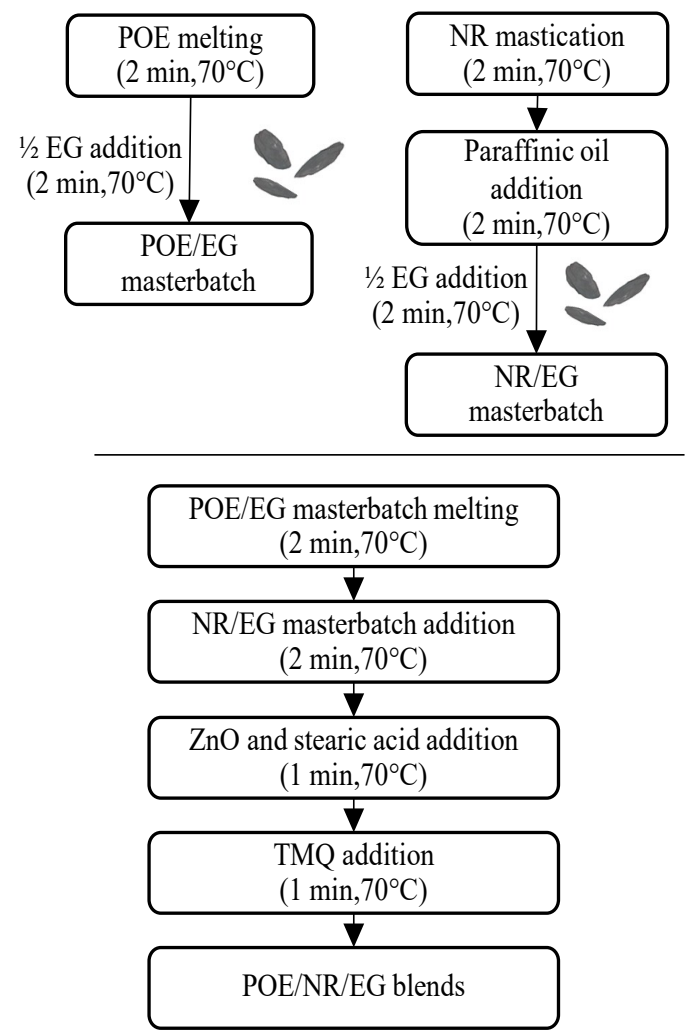

Fig. 1 Schematic diagram of the preparation of POE/NR/EG blend foam.

Table 1 Compounding formulation of POE/NR/EG blend.

\begin{tabular}{lc}
\hline \multicolumn{1}{c}{ Components } & $\begin{array}{c}\text { Quantities } \\
\text { (part(s) per hundred } \\
\text { rubbers, phr) }\end{array}$ \\
\hline POE/NR & 100 \\
Paraffinic oil & 20 \\
Expandable graphite (EG) & 20 \\
Zinc oxide (ZnO) & 3 \\
Stearic acid & 1 \\
2, 2, 4-Trimethyl-1, 2-dihydroquinone & 2 \\
(TMQ) & \\
\hline
\end{tabular}




\section{Characterization}

\section{Rheological measurement}

Rheological properties of the EG filled POE/NR blends were measured by using a rotational rheometer, D-RPA 3000 (Montech $^{\circledR}$ Rubber Testing Solutions, Buchen, Germany) with a parallel-plate geometry. The tests were performed in the oscillating frequency range of 0.01 to $80 \mathrm{~Hz}$ at $160{ }^{\circ} \mathrm{C}$ with strain of $0.6 \%$.

\section{Scanning electron microscopy (SEM)}

The cellular structure of EG-filled POE/NR blends was investigated by using scanning electron microscopy (SEM; FEI Quanta 400 FEG, Oregon, USA). The samples were immersed in liquid nitrogen and razor cut. The samples were later sputter-coated with a thin layer of gold to avoid electrical charging during examination. The SEM photomicrographs of razor cut surfaces were taken at magnification of X100. The cell size was determined by measuring the maximum diameter of each cell and cell density $\left(\mathrm{N}_{f}\right)$, or the number of cell per unit volume was calculated from Equation (1)

$$
\mathrm{N}_{\mathrm{f}}=\left(\mathrm{nM}^{2} / \mathrm{A}\right)^{2 / 3}
$$

where $\mathrm{n}$ is the number of cells on the SEM photomicrograph, $\mathrm{M}$ is the magnification factor, and $\mathrm{A}$ is the area of the micrograph $\left(\mathrm{cm}^{2}\right)$.

\section{Density measurement}

Density of the foamed EVA/NR blends was determined by mean of mass-to-volume ratio of the samples according to ASTM D162293.

\section{Gel content measurement}

Crosslink density of the foamed samples was determined by gel content analysis. The test-pieces of foams were boiled with xylene for $24 \mathrm{~h}$ to remove uncrosslinked rubber in the blend foams. The extracted samples were dried to constant weight at room temperature for 2 days. The gel content was calculated as the ratio of weight of dried sample after the extraction (A) to the initial weight of the sample before extraction (B) as following Equation (2) (Lopattananon et al., 2014b).

$\%$ Gel content $=(\mathrm{A}-$ Weight of filler $/ \mathrm{B}-$ Weight of filler $) \times 100$

\section{Mechanical property measurement}

The tensile testing was performed on Hounsfield Tensometer model H10KS (Hounsfield Test Equipment Co., Ltd, UK) in accordance with ASTM D412-98a. The dumbbell-shaped test specimens were cut from the vulcanized rubber foams. The specimens were stretched at room temperature $\left(25 \pm 2{ }^{\circ} \mathrm{C}\right)$ with extension rate of $500 \pm 50 \mathrm{~mm} / \mathrm{min}$. The compression load-deflection measurements were performed using Hounsfield Tensometer (model H10KS) in accordance with the procedure described in ASTM D 790. The crosshead speed was $12 \mathrm{~mm} / \mathrm{min}$. The load was applied until the foam was compressed to $70 \%$ of its original thickness. The mean tensile properties and compressive strength were averaged from five measurements. The compression set test was performed as per ASTM D395-03. The foamed samples with dimension of $2 \times 2 \mathrm{~cm}^{2}$ were compressed by $50 \%$ for $6 \mathrm{~h}$ at $50{ }^{\circ} \mathrm{C}$ before cooling down at room temperature for $30 \mathrm{~min}$, and the final sample thickness was measure. The compression set was calculated using Equation (3) as follows:

$$
\% \text { Compression set }=\left[\left(\mathrm{t}_{0}-\mathrm{t}_{\mathrm{f}}\right) /\left(\mathrm{t}_{0}-\mathrm{t}_{\mathrm{n}}\right)\right] \times 100
$$

where $\mathrm{t}_{0}$ is the original thickness of the test-specimen $(\mathrm{mm}), \mathrm{t}_{f}$ is the final thickness of the test-specimen $(\mathrm{mm})$, and $t_{n}$ is the spacer thickness.

\section{Thermal conductivity Analysis (TCA)}

The thermal conductivity was measured using UNITHERMTM Model 2022 (Anter Corp., US). The test was in accordance with
ASTM E-1530 standard. The test specimen was in a square form with dimension of $10 \times 10 \times 2 \mathrm{~mm}^{3}$.

\section{Flammability tests}

The fire resistance of the foamed samples was evaluated by Limiting Oxygen Index (LOI) measurement. The LOI test was measured using a Limiting Oxygen Index Flammability tester (Yasuda Seiki Seisakusho, Yamaguchi-cho, Japan) on samples with dimensions of $10 \times 150 \times 3 \mathrm{~mm}^{3}$, in accordance with ASTM D2863. The horizontal burning test was performed using an FTT (Fire Testing Technology, Surrey, UK) Horizontal/Vertical Flame Chamber (UL 94) on samples with a dimension of $50 \times 150 \times 13 \mathrm{~mm}^{3}$ according to ASTM D4986. The test results were classified by burning ratings: HF1 and HF2. HF1 rating illustrates the flame-retarded foamed materials, which the afterflame stops within $2 \mathrm{~s}$; afterglow less than $30 \mathrm{~s}$ and HF2 rating exhibits afterflame stops within $3 \mathrm{~s}$; afterglow less than $30 \mathrm{~s}$ and burning drips are observed.

\section{RESULTS AND DISCUSSION}

\section{Rheological properties of POE/NR/EG blend foams}

The strength and viscosity of molten polymers are important factors in processing ability of polymer foams (Yamagushi \& Suzuki, 2001). hence, the rheological properties of the POE/NR/EG blend compounds without ADC were determined to study the influence of DCP content on the viscoelastic properties, i.e, storage shear modulus $\left(\mathrm{G}^{\prime}\right)$, loss shear modulus $\left(\mathrm{G}^{\prime \prime}\right)$, and complex viscosity $\left(\eta^{*}\right)$ of the blends.
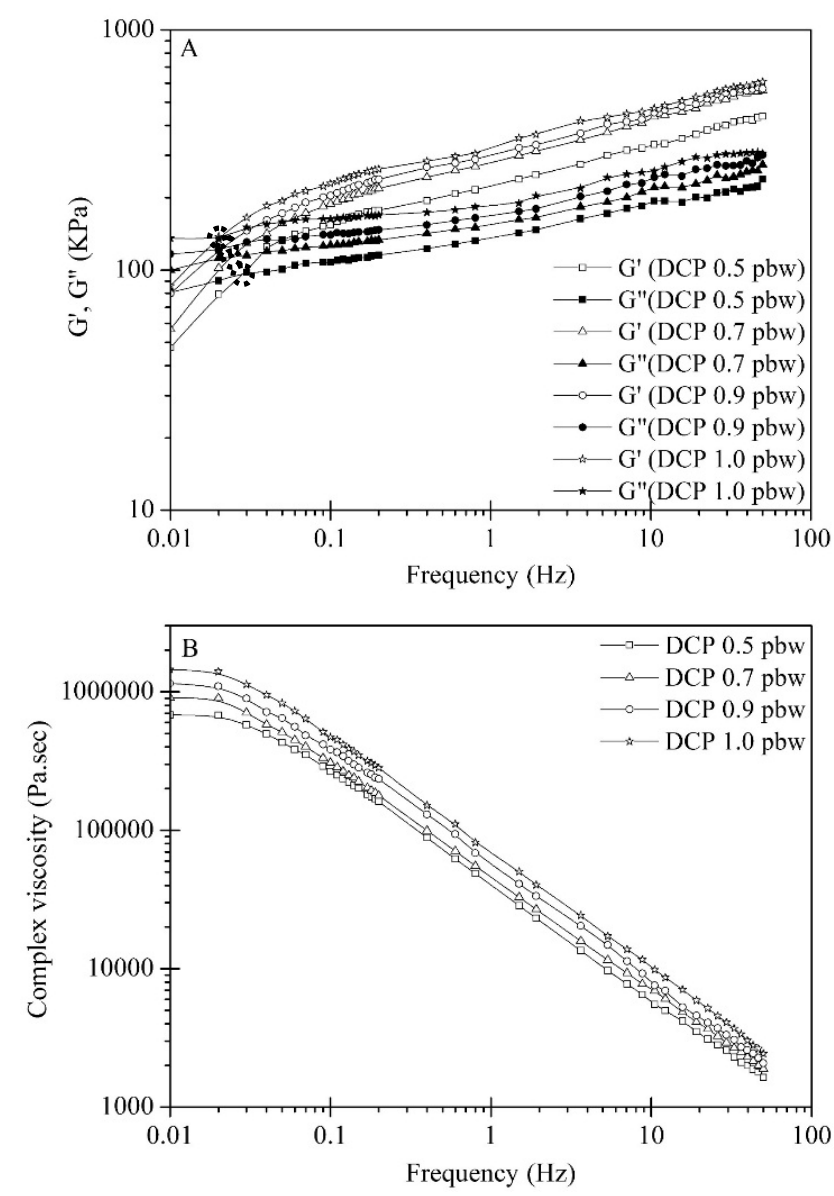

Fig. 2 Rheological properties of POE/NR/EG blend foams containing different DCP contents.

Fig. 2 shows the changes of storage shear modulus, loss shear modulus and complex viscosity at $160^{\circ} \mathrm{C}$ as a function of frequency for the various $\mathrm{POE} / \mathrm{NR} / \mathrm{EG}$ blends added with different contents of DCP. The $\mathrm{G}^{\prime}$ represents elastic response while the $\mathrm{G}^{\prime \prime}$ is viscous response. It is seen that the values of $G^{\prime}$ and $G^{\prime \prime}$ for all the blend 
foams increase with increasing frequency (Fig. 2A). When the rate of deformation increases, the time that the rubber chains required to reorganize themselves is shorter, leading to higher stored elastic energy (or $\mathrm{G}^{\prime}$ ) and viscous dissipation $\left(\mathrm{G}^{\prime \prime}\right)$ (Li et al., 2013). At the beginning of the test (low-frequency regime), the values of elastic modulus were quite lower than those of the viscous modulus, and the elastic modulus were then greater than the loss modulus as they approached higher frequency. The crossover point indicated by circle, where the value of $\mathrm{G}^{\prime}$ is equal to that of $\mathrm{G}^{\prime \prime}$, is denoted as gelation point (Muller et al., 1991). The frequency at crossover of $\mathrm{G}^{\prime}$ and $\mathrm{G}^{\prime \prime}$ shifts to the left when the DCP content is increased as shown in Fig. 2A. This qualitatively indicated the presence of larger molecules in the POE/NR/EG blends (Kamleitner et al., 2017). It is also seen that the storage modulus increased with the increasing amount of DCP due to stiffness imparted by the crosslinking structure driven through the addition of DCP in the blends. Furthermore, the enhancement of $\eta^{*}$ with more DCP is obvious in Fig. 2B. When the chemical crosslinking was formed in the rubber blends, the flow of the rubber chains was reduced, leading to higher viscosity.

To substantiate the role of crosslinking structure formed by DCP addition on the rheological properties of POE/NR/EG blend foams, we evaluated the gel content of the different blend foams containing $0.5-1.0 \mathrm{pbw}$ DCP, and the results are shown in Fig. 3. The data indicate that increasing amount of DCP from 0.5 to $1.0 \mathrm{pbw}$ could increase the gel content, which corresponded to an increase of crosslink level of the blend foams. These results clearly suggest that the POE/NR/EG blends showed increased melt strength and viscosity with increasing DCP content due to a promotion of crosslinking structure in the blends.

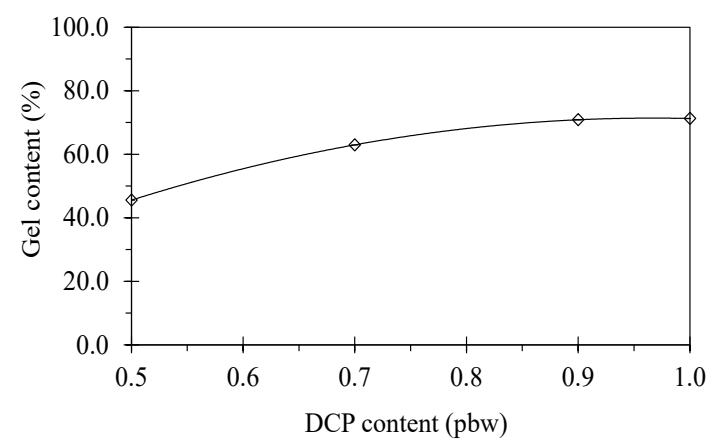

Fig. 3 Variation of gel content for POE/NR/EG blend foams as a function of the DCP content.

\section{Morphology of POE/NR/EG blend foams}

Generally, the performance of polymer foams could be evaluated by many parameters, such as cell size, cell density, and cell size distribution. Fig. 4 shows the SEM images of cellular structure and the cell size distribution for the EG filled 60/40 POE/NR foams with different DCP contents. The data of cell size distribution, cell density, average cell size, and foam density for the blend foams containing different DCP concentrations are tabulated in Table 2. From Fig. 4, it can be seen that the EG filled POE/NR blend foams exhibit closedcell structure. At very low DCP content $(0.5 \mathrm{pbw})$, several large cells among small cells are observed (Fig. 4A). Furthermore, the blend foams show a broad distribution of cell size with cell size in a range of $41-311 \mu \mathrm{m}$ and average cell size of $131 \mu \mathrm{m}$. Increasing DCP content resulted in more small cells and the cell size distribution becoming narrower. In case of foaming with $0.5 \mathrm{pbw}$ DCP, the blend exhibits low melt strength, which does not facilitate the stabilization of cell structure, so the large cells with broad cell size are obtained. With higher DCP concentration ( $0.7 \mathrm{pbw})$, the degree of crosslinking in the blend foams increase, promoting the melt strength/viscosity as previously discussed (Figs. 2A-2B). The enhanced melt strength/viscosity hindered the cell growth and suppressed the cell rupture and coalescence to some extent, thus resulted in the formation of smaller cells and more uniform cell size distribution as shown in Fig. 4B. The presence of more crosslinking agent (at DCP content greater than $0.7 \mathrm{pbw})$ further restricted the cell growth. The decomposition gas from ADC dissociation inside the cells would not be able to expand each wall outward due to high melt strength of the rubber blend and consequently gave rise to smaller cells (the leftward shift of cell size distribution) with thicker cell wall as clearly supported by the SEM image in Figs. 4C-4D.

Furthermore, Table 2 shows the detailed data of cellular structure obtained from the SEM images for the different blend foams. The data indicate that the cell density increase with increasing DCP content from $0.5 \mathrm{pbw}$ to $0.7 \mathrm{pbw}$ and then decrease with higher DCP content, whereas the average cell size decrease with increasing DCP content as a result of higher crosslinking level. The initial increase in cell density was attributed to the obstruction of cell growth and cell coalescence as discussed earlier. Thus, the blend foams added with $0.7 \mathrm{pbw}$ DCP had more cells per volume than that of 0.5 pbw DCP (Figs. 4A-4B). This led to more rubber phase than gas phase as reflected by an increase in relative foam density (Table 2). As the DCP content exceeds 0.7 pbw, the cell density decreases mainly because the excessive crosslinking rubber increases the melt strength/viscosity of the blends (Fig. 2) which could hinder the cell nucleation (Mao \& Qi, 2008) and restrict the cell growth, and thereby reducing the cell density and expansion of the blend foams, respectively. A greater restriction towards expansion also gave rise to increase cell wall thickness, therefore producing higher foam density (Table 2).
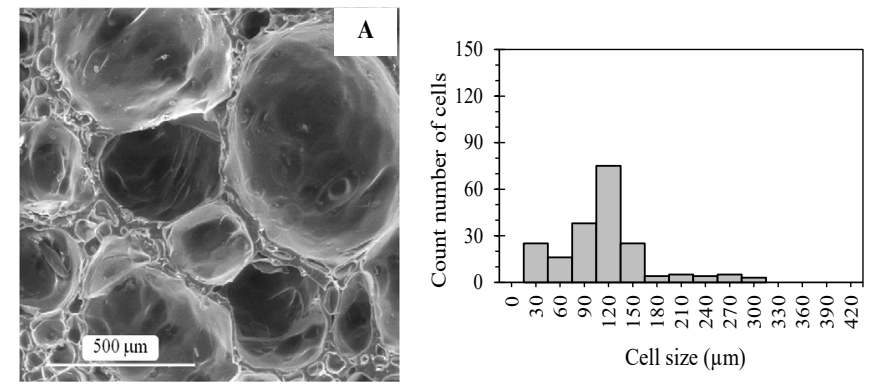

Cell size $(\mu \mathrm{m})$
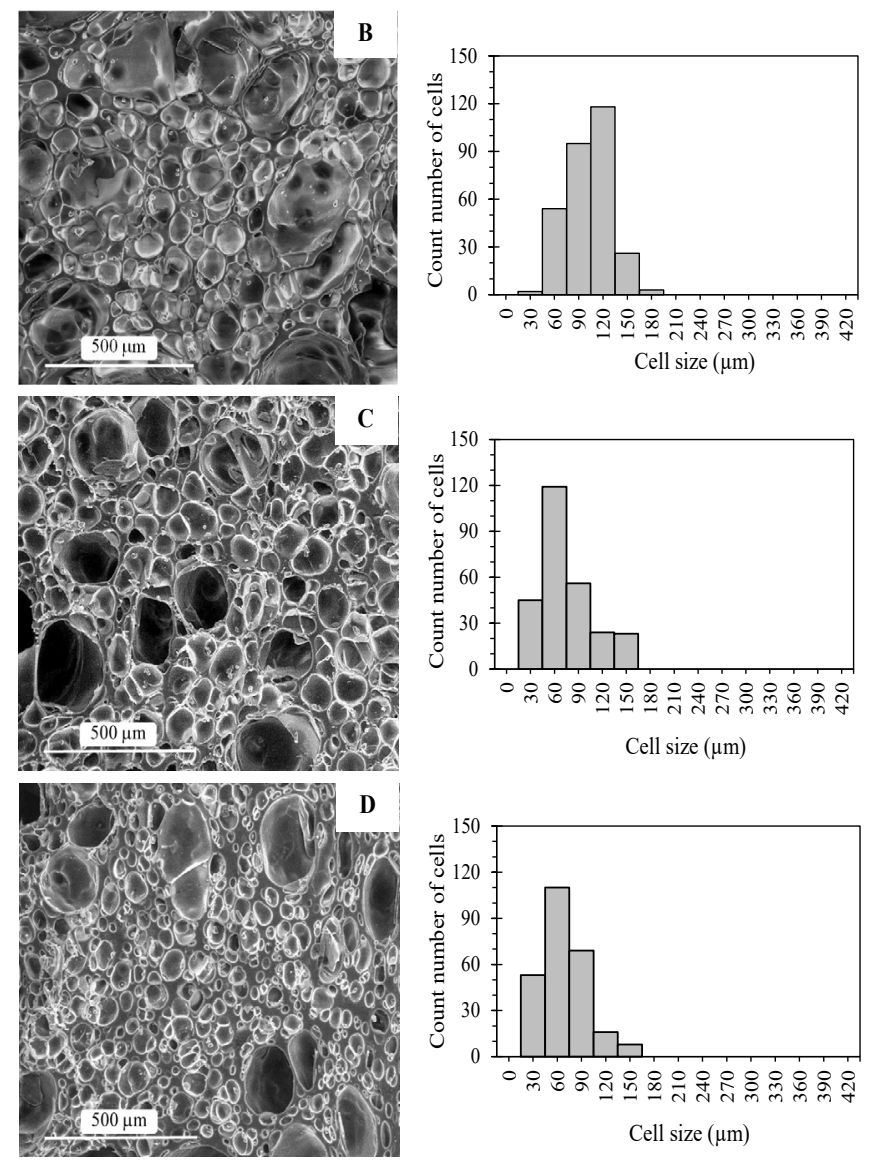

Fig. 4 SEM photomicrographs of POE/NR/EG blend foams containing DCP of (A) $0.5 \mathrm{pbw},(\mathrm{B}) 0.7 \mathrm{pbw},(\mathrm{C}) 0.9 \mathrm{pbw}$ and (D) $1.0 \mathrm{pbw}$, respectively. 
Table 2 Cell size distribution, cell density and cell size of-POE/NR/EG blend foams containing different contents of DCP.

\begin{tabular}{ccccc}
\hline $\begin{array}{c}\text { DCP content } \\
(\mathbf{p b w})\end{array}$ & $\begin{array}{c}\text { Cell size distribution } \\
(\boldsymbol{\mu m})\end{array}$ & $\begin{array}{c}\text { Cell density, } \mathbf{N}_{\mathbf{f}} \\
\left(\mathbf{c e l l s} / \mathbf{c m}^{3}\right)\end{array}$ & $\begin{array}{c}\text { Average cell size } \\
(\boldsymbol{\mu m})\end{array}$ & $\begin{array}{c}\text { Density } \\
\left(\mathbf{g} / \mathbf{~ c m}^{3}\right)\end{array}$ \\
\hline 0.5 & $41-311$ & $19.41 \times 10^{6} \pm 0.73 \times 10^{6}$ & $131.81 \pm 53.05$ & $0.159 \pm 0.007$ \\
0.7 & $17-176$ & $26.23 \times 10^{6} \pm 0.35 \times 10^{6}$ & $92.48 \pm 21.15$ & $0.168 \pm 0.003$ \\
0.9 & $16-153$ & $17.31 \times 10^{6} \pm 0.42 \times 10^{6}$ & $69.57 \pm 51.49$ & $0.241 \pm 0.010$ \\
1.0 & $16-147$ & $15.45 \times 10^{6} \pm 0.61 \times 10^{6}$ & $59.30 \pm 49.11$ & $0.252 \pm 0.007$ \\
\hline
\end{tabular}

\section{Mechanical properties of POE/NR/EG blend foams}

As the mechanical properties of polymer foams are important factors determining their applications, such as in load bearing and construction, it is necessary to study the mechanical properties of $\mathrm{POE} / \mathrm{NR} / \mathrm{EG}$ blend foams. Several factors, i.e., rigidity of polymer (Lopattananon et al., 2014a), cellular structure (Lopattananon et al., 2015; Lopattananon et al., 2018a), and foam density (Lopattananon et al., 2014a; Lopattananon et al., 2015; Lopattananon et al., 2018a) have been established to affect the mechanical properties of polymeric foams.

Fig. 5 shows the effect of DCP content on the mechanical properties of the EG-filled POE/NR blend foams. As the DCP content increases, the tensile strength also increases, but the elongation at break decreases (Figs. 5A-5B). According to the gel content measurement results shown in Fig. 3, increasing the level of crosslinking would increase the stiffness of the materials in the cell walls, which allowed the blend foams to experience higher stress and yielded less extent of deformation before failure. Fig. 5C shows the variation of compression set of the blend foams with varying DCP contents. From Fig. 5C, it is seen that the compression set decreased with increasing DCP content. The increased chemical linkages formed between the rubber chains by the crosslinking process of dicumyl peroxide could progressively improve the resistance to the deformation under the prolonged press during measurement of compression set. Thus, the compression set with more DCP incorporation was raised. This behavior meant that the elastomeric recovery of the rubber blend foams was enhanced by the increment of DCP content. Fig. 5D shows that the compressive strength of the blend foams also increased with increasing DCP content. Noted that the low-relative density foams had distributed large cells with thinner cell walls than the high-relative density foams (Fig. 4 and Table 2). The low-relative density foam would easily fail due to buckling of cell wall and a sudden collapse through cell wall at low compressive stress (Subhash et al., 2006). On the other hand, the high-relative density foam with distributed small cells and greater cell wall thickness could undergo higher strain deformation and resist loads under pressure from compression. Therefore, the compressive strength of the blend foams increases with increasing DCP content.

\section{Thermal conductivity of POE/NR/EG blend foams}

The thermal conductivity of the various EG-filled POE/NR blend foams was determined to compare the thermal insulation performance. Fig. 6 shows the effect of DCP content on the thermal conductivity of the EG-filled POE/NR blend foams. As can be seen from Fig. 6, the thermal conductivity of the blend foams is reduced from 0.067 to $0.056 \mathrm{~W} / \mathrm{m} \cdot \mathrm{K}$ when the DCP content is increased from $0.5 \mathrm{pbw}$ to 0.7 pbw. This indicates that the thermal insulation has been improved. It was reported that a foam consisting of a large number of small cells will transfer less heat radiatively than the material comprising small number of larger cells (Fyodor \& Shutov, 1991). As a result, the presence of higher cell density and smaller cells in the blend foams when the DCP content is increased from 0.5 to $0.7 \mathrm{pbw}$ (Table 2) resulted in less radiative heat transfer through the cell walls. However, at higher DCP content (0.9-1.0 pbw), the blend foam showed higher thermal conductivity $(0.073-0.074 \mathrm{~W} \mathrm{~W} / \mathrm{m} \cdot \mathrm{K})$. As given in Table 2 , the cell density decreases with increased addition of DCP content from $0.9-1.0 \mathrm{pbw}$, while the change in average cell size is not obvious. This generated more heat transfer in the blend foams and reduced the thermal insulation properties.
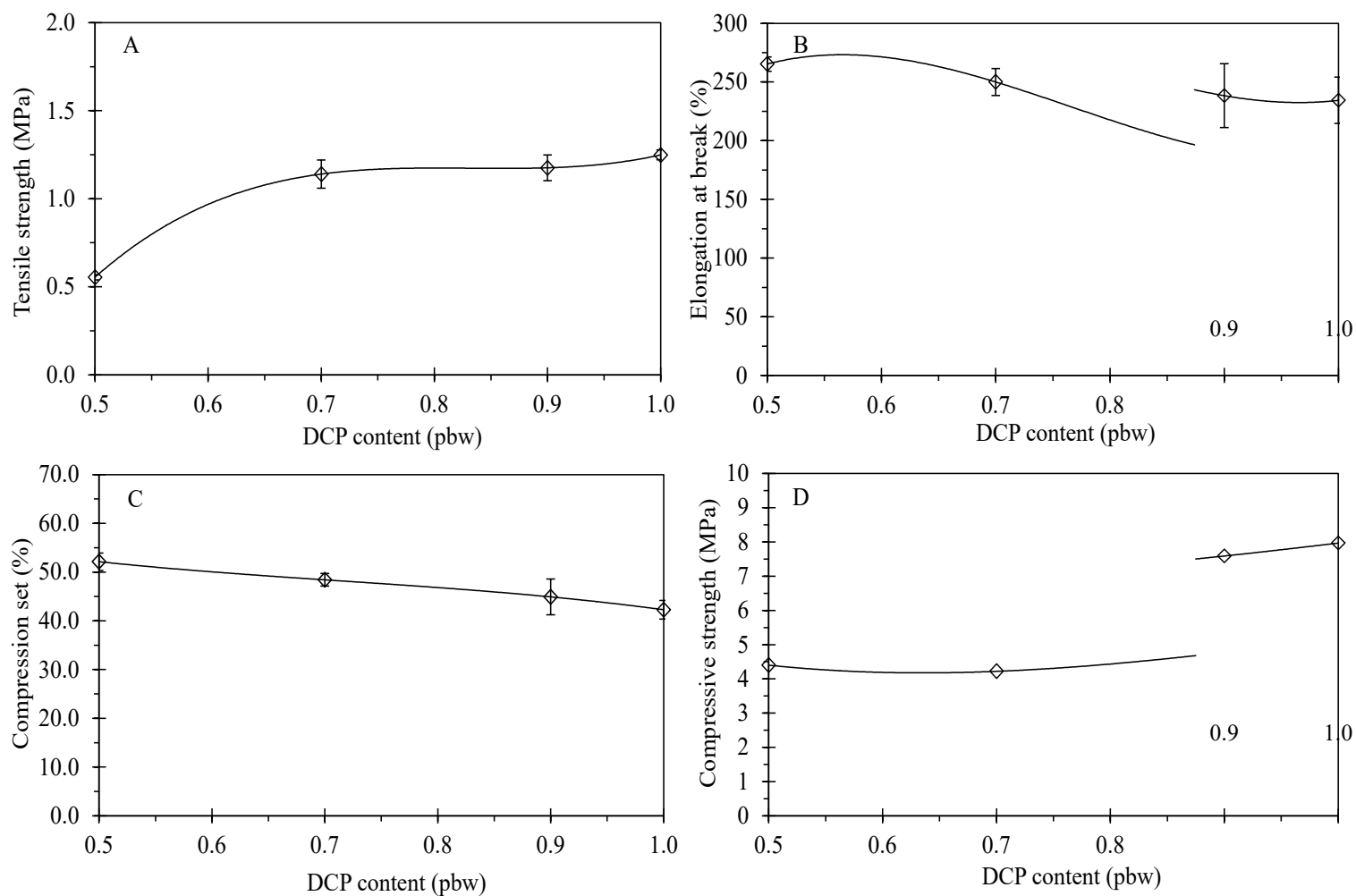

Fig. 5 Variation of $(A)$ tensile strength, (B) elongation at break, (C) compression set and (D) compressive strength for POE/NR/EG blend foams as a function of the DCP content. 


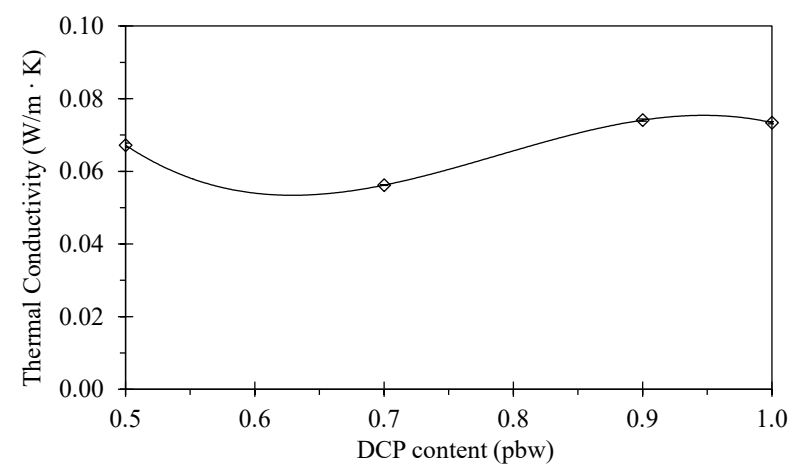

Fig. 6 Variation of thermal conductivity for POE/NR/EG blend foams as a function of the DCP content.

\section{Fire retardancy of POE/NR/EG blend foams}

Table 3 shows the results obtained from horizontal burning test and LOI measurement for the various EG-filled POE/NR blend foams with different added DCP contents. From the table, all blend foams show the classification of HF-1, which indicate that the POE/NR/EG blend foams are good fire-retardant materials. Upon heating, the EG flame retardant expands to voluminous worm-like structure as shown in Fig. 7. The expanded worm-graphite char layer covering the entire burning surface could reduce heat and oxygen transfer to the underneath materials, therefore efficiently lowered the decomposition and combustion of the rubber blend foams (Xi et al., 2016; Li et al., 2018; Kurańska et al., 2016; Zheng et al., 2016). Furthermore, the LOI value of the blend foams containing $20 \mathrm{phr}$ EG gradually increased with increasing DCP content, implying that the fire resistance of foamed blends was enhanced. The increase of LOI value may be due to increased density of the blend foams with increasing DCP content (Table 2). The density increase would result in more rubber mass to volume, which caused higher amount of EG concentration per volume. This characteristic was clearly confirmed by the increased formation of expanded graphite worms along with high-volume expanded worms on the surfaces of burned POE/NR/EG blend foam with higher DCP content as shown in Fig. 7. As a result, the larger volume of EG char layer to protect the underlying foamed rubbers from heat and combustion was developed, and the LOI values were increased.

Table 3 Horizontal burning level (HF) and limiting oxygen index (LOI) of $\mathrm{POE} / \mathrm{NR} / \mathrm{EG}$ blend foams containing different contents of DCP.

\begin{tabular}{ccc}
\hline $\begin{array}{c}\text { DCP content } \\
\text { )pbw( }\end{array}$ & HF Rating & $\begin{array}{c}\text { LOI } \\
(\%)\end{array}$ \\
\hline 0.5 & HF-1 & 38.0 \\
0.7 & HF-1 & 39.2 \\
0.9 & HF-1 & 40.0 \\
1.0 & HF-1 & 41.0 \\
\hline
\end{tabular}

\section{CONCLUSION}

Crosslinked POE/NR blend-based foams filled with EG flame retardant were produced by using DCP at different contents $(0.5,0.7$, 0.9 , and $1.0 \mathrm{pbw}$ ). The rheological measurement showed that the melt strength and viscosity of the blend foams increased with increased introduction of DCP. The finer foam characterized by SEM analysis was observed with the foamed sample crosslinked by using $0.7 \mathrm{pbw}$ DCP. With the increase of DCP concentration, the foam density, tensile strength, elastomeric recovery, and compressive strength also increased due to an increased crosslinking level, meanwhile the elongation at break decreased. The lowest value of thermal conductivity for the EG filled POE/NR blend foam was also attained for the POE/NR/EG blend foam added with $0.7 \mathrm{pbw}$ of DCP. Furthermore, the POE/NR/EG blend foams achieved HF-1 rating of horizontal burning test, and their LOI values were enhanced from 38 to $41 \%$ with higher addition of DCP. In this study, the finding suggested that the use of DCP at 0.7 pbw provided the optimum foam morphology along with the best improvement in thermal insulation properties and good flame retardancy for preparation of POE/NR/EG blend foams.
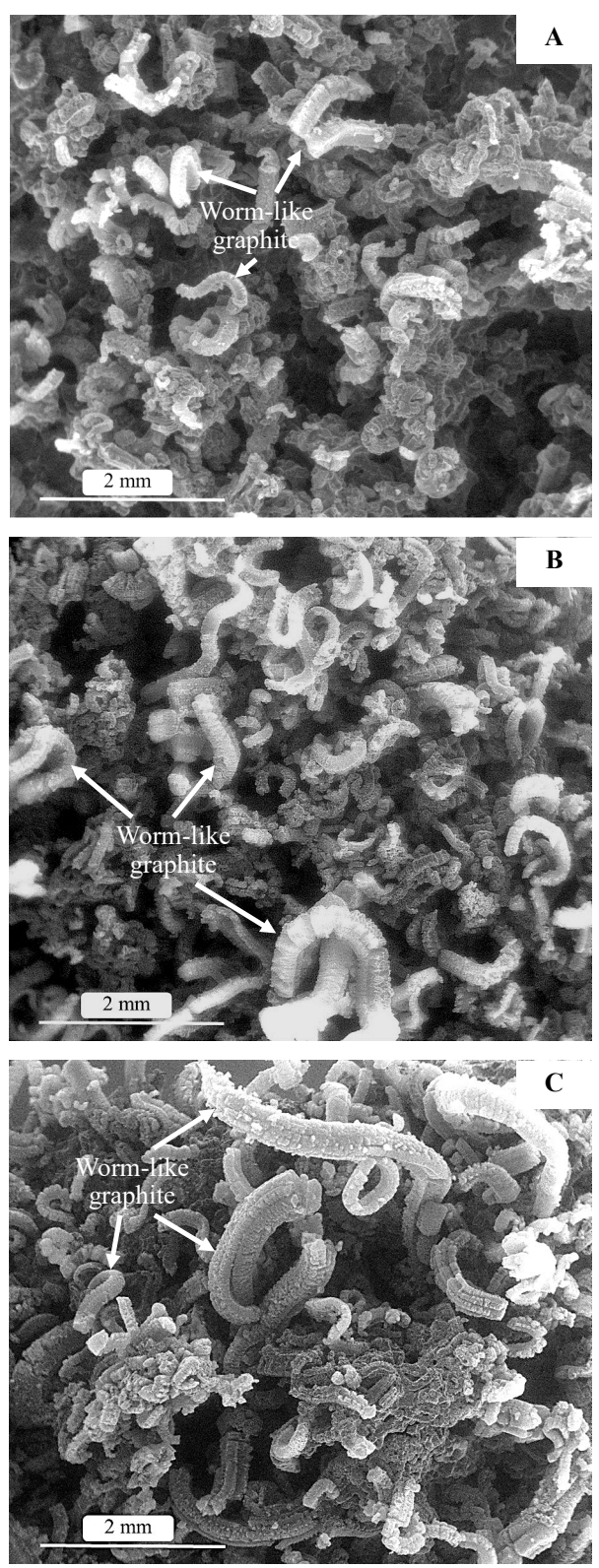

Fig. 7 Representative worm-like graphite layer taken after burning of $\mathrm{POE} / \mathrm{NR} / \mathrm{EG}$ blend foams containing DCP of (A) $0.5 \mathrm{pbw}$, (B) $0.7 \mathrm{pbw}$ and (C) 1.0 pbw, respectively.

\section{ACKNOWLEDGEMENT}

We would like to acknowledge the Natural Rubber Innovation Research Institute with Contract number SAT610275S and the Graduate School, Prince of Songkla University, Thailand for the financial supports provided.

\section{REFERENCES}

Bian, X.-C., Tang, J.-H., Li, Z.-M., Lu, Z.-Y., Lu, A. (2007). Dependence of flame-retardant properties on density of expandable graphite filled rigid polyurethane foam. Journal of Applied Polymer Science, 104(5), 33473355 .

Chen, X., Wu, H., Luo, Z., Yang, B., Guo, S., Yu, J. (2007). Synergistic effects of expandable graphite with magnesium hydroxide on the flame retardancy and thermal properties of polypropylene. Polymer Engineering and Science, 47, 1756-1760.

Cornish, K. (2014). Biosynthesis of natural rubber (NR) in different rubberproducing species. In S. Kohjiya \& Y. Ikeda (Eds.), Chemistry, manufacture and applications of natural rubber (1st ed.). Cambridge: Woodhead publishing, 
Feng, Z., Luo, Y., Hong, Y., Wu, J., Zhu, J., Li, H., Qi, R., Jiang, P. (2016). Preparation of enhanced poly (butylene succinate) foams. Polymer Engineering and Science, 56(11), 1275-1282.

Fyodor, A. D., Shutov, A. (1991). Chapter 3: Cellular structure and properties of foamed polymers. In D. Klemper \& K. C. Frisch (Eds.), Handbook of Polymeric Foams and Foam Technology (2nd ed.). Munich: Hanser Publishers.

Guler, T., Tayfun, U., Bayramli, E., Dogan, M. (2017). Effect of expandable graphite on flame retardant, thermal and mechanical properties of thermoplastic polyurethane composites filled with huntite and hydromagnesite mineral. Thermochimica Acta, 647, 70-80.

Guo, R., Ren, Z., Bi, H., Song, Y., Xu, M. (2018). Effect of toughening agents on the properties of poplar wood flour/poly (lactic acid) composites fabricated with fused deposition modeling. European Polymer Journal, $107,34-45$.

Jacob, S. (2008). US Patent 7,319,121 B2. Retrieved fromhttp://patents.com /us-7319121.html

Julyanon, J., Kaesaman, A., Sakai, T., Lopattananon, N. (2015). Improvement of structure and properties of nanocomposite foams based on ethylenevinyl actetae (EVA)/natural rubber (NR)/nanoclay: Effect of NR addition. Key Engineering Materials, 659, 418-422.

Kamleitner, F., Duscher, B., Koch, T., Knaus, S., Schmid K., Archodoulaki, V. M. (2017) Influence of the molar mass on long chain branching of polypropylene. Polymers, 9(442), 1-15.

Kurańska, M., Cabulis, U., Auguścikc, M., Prociak, A., Ryszkowska, J., Kirpluks, M. (2016). Bio-based polyurethane-polyisocyanurate composites with an intumescent flame retardant. Polymer Degradation and Stability, $127,11-19$

Li, G., Qi, R., Lu, J., Hu, X., Luo, Y., Jiang, P. (2013). Rheological properties and foam preparation of biodegradable poly (butylene succinate). Journal of Applied Polymer Science, 127(5), 3586-3594.

Li, L., Chen, Y., Qian, L., Xu, B., Xi, W. (2018). Addition flame-retardant effect of nonreactive phosphonate and expandable graphite in rigid polyurethane foams. Journal of Applied Polymer Science, 135(45960), 18.

Lopattananon, N., Wongpradit, N., Nakason, C., Kaesaman, A. (2014a). Effect of rubber compositions on foaming and properties of EVA/NR thermoplastic vulcanizates (TPVs). Journal of Rubber Research, 17, 8095.

Lopattananon, N., Tanglakwaraskul, S., Kaesaman, A., Seadan, M., Sakai, T. (2014b). Effect of nanoclay addition on morphology and elastomeric properties of dynamically vulcanized natural rubber/polypropylene nanocomposites. International Polymer Processing, 29(3), 332-341.

Lopattananon, N., Julyanon, J., Masa, A., Kaesaman, A., Thongpin, C., Sakai, T. (2015). The role of nanofillers on NR/EVA/Clay nanocomposite in blending and foaming. Journal of Vinyl \& Additive Technology, 21(2), $134-146$.

Lopattananon, N., Julyanon, J., Masa, A., Thongnuanchan, B. (2018a). Effect of the addition of ENR on foam properties of EVA/NR/clay nanocomposites. International Polymer Processing, 33(1), 42-51.

Lopattananon, N., Walong, A., Sakai, T. (2018b). Influence of incorporation methods of ATH on microstructure, elastomeric properties, flammability, and thermal decompositionof dynamically vulcanized NR/PP blends. Journal of Applied Polymer Science, 135(46231), 1-12.

Lorenzetti, A., Dittrich, B., Schartel, B., Roso, M., Modesti, M. (2017) Expandable graphite in polyurethane foams: The effect of expansion volume and intercalants on flame retardancy. Journal of Applied Polymer Science, 134(45173), 1-8.
Mao, Y., Qi, R. (2008). Preparation of polyethylene-octene elastomer foams by compression molding. Journal of Applied Polymer Science, 109(5), 3249-3255.

Mngomezulu, M. E., Luyt, A. S., Chapple S. A., John, M. J. (2018) Effect of expandable graphite on thermal and flammability properties of poly (lactic acid)-starch/poly(E-caprolactone) blend systems. Polymer Engineering and Science, 58(9), 1619-1629.

Muller, R., Gérald, V., Dugand, P., Rempp, P., Gnanou, Y. (1991). Rheological characterization of the gel point: A new interpretation. Macromolecules, 24(6), 1321-1326.

Pang, X.-Y., Chang, W.-S., Chang, R., Weng, M-Q. (2018). Influence of titanium dioxide modified expandable graphite and ammonium polyphosphate on combustion behavior and physicomechanical properties of rigid polyurethane foam. International Polymer Processing, 33(1), 117 126.

Shi, L., Li, Z.-M., Zhou, Q-M., Yang, M.-B., Yin, B., Tian, C.-R., et al. (2005). Expandable graphite for halogen-free flame-retardant of highdensity rigid polyurethane Foams. Polymer-Plastics Technology and Engineering, 44(7), 1323-1337.

Shih, R-S., Kuo, S-W., Chang, F-C. (2011). Thermal and mechanical properties of microcellular thermoplastic SBS/PS/SBR blend: Effect of crosslinking. Polymer, 52(3), 752-729.

Spratte, T., Plagge, J., Wunde, M., Klüpple, M. (2017). Investigation of straininduced crystallization of carbon black and silica filled natural rubber composites based on mechanical and temperature measurements. Polymer, $115,12-20$.

Subhash, G., Liu, Q., Gao, X. L. (2006). Quasistatic and high strain rate uniaxial compressive response of polymeric structural foams. International Journal of Impact Engineering, 32(7), 1113-1126.

Sun, X., Liang, W. (2016). Cellular structure control and sound absorption of polyolefin microlayer sheets. Composites Part B: Engineering, 87, 21-26.

Svoboda, P., Poongavalappil, S., Theravalappil, R., Svobodova, D., Mokrejs, P. (2013). Effect of octene content on peroxide crosslinking of ethyleneoctene copolymers. Polymer International, 62(2), 184-189

Tayefi, M., Razavi-Nouri, M., Sabet, A. (2017). Influence of ordering and disordering of organoclay on rheological properties of uncured and cured ethylene-octene copolymer nanocomposites. Applied Clay Science, 83, 357-366.

Thirumal, M., Khastgir, D., Singha, N. K., Munjunath, B. S., Naik, Y. P. (2008). Effect of expandable graphite on the properties of intumescent flame-retardant polyurethane foam. Journal of Applied Polymer Science, $110(5), 2586-2594$.

Wang, S., Qian, L., Xin, F. (2018). The synergistic flame-retardant behaviors of pentaerythritol phosphate and expandable graphite in rigid polyurethane foams. Polymer Composites, 39(2), 329-336.

Xi, W., Qian, L., Huang, Z., Cao, Y., Li, L. (2016). Continuous flame-retardant actions of two phosphate esters with expandable graphite in rigid polyurethane foams. Polymer Degradation and Stability, 130, 97-102.

Yamagushi, M., Suzuki, K.-I. (2001). Rheological properties and foam processability for blends of linear and crosslinked polyethylenes. Journal of Polymer Science Part B: Polymer Physics, 39(18), 2159-2167.

Zhang, Y., Chen, X., Fang, Z. (2013). Synergistic effects of expandable graphite and ammonium polyphosphate with a new carbon source derived from biomass in flame retardant ABS. Journal of Applied Polymer Science, 128(4), 2424-2432.

Zheng, Z., Liu, Y., Zhang, L., Wang, H. (2016). Synergistic effect of expandable graphite and intumescent flame retardants on the flame retardancy and thermal stability of polypropylene. Journal of Materials Science, 51(12), 5857-5871. 